\title{
Susceptibility of Biomphalaria amazonica and Biomphalaria occidentalis from Manso Dam, Mato Grosso, Brazil to infection with three strains of Schistosoma mansoni
}

\author{
Monica Ammon Fernandez ${ }^{+}$, Silvana Carvalho Thiengo
}

\author{
Departamento de Malacologia, Instituto Oswaldo Cruz-Fiocruz, Av. Brasil 4365, 21040-900 Rio de Janeiro, RJ, Brasil
}

\begin{abstract}
As well as malaria and yellow fever, schistosomiasis is one of the main endemic diseases associated to environments which suffered some impact related to the development of great economic projects, as for example the construction of hydroelectric power stations. Aiming to investigate the occurrence and distribution of freshwater snails of medical and veterinary importance in the area which suffered impact from the Manso hydroelectric power station a survey was performed during the period of 2002 to 2003 and revealed the occurrence of populations of Biomphalaria amazonica and Biomphalaria occidentalis. Studies on parasite-mollusc compatibility were undertaken using five B. amazonica colonies (Barão de Melgaço, Poconé, Santo Antônio do Leverger, and Chapada dos Guimarães, in the Manso and Casca rivers), and four B. occidentalis colonies (Cuiabá, Santo Antônio do Leverger, and Chapada dos Guimarães, in the Água Fria district and Casca river) were exposed to miracidia of Schistosoma mansoni. Of 257 snails of B. amazonica used, 17 became infected (infection index of 6.61\%) and all specimens of B. occidentalis proved unsusceptible. According to the strains used, of the 158 snails exposed to BH miracidia, 6 became infected (3.79\%); of the 44 exposed to SJ miracidia, 6 became infected (13.63\%); and of the 55 snails of B. amazonica exposed to EC miracidia, 5 became infected (9.09\%). These results point out the low possibility of introduction of schistosomiasis in those areas, but we believe it can not be discarded as due the presence of $\mathrm{B}$. amazonica.
\end{abstract}

Key words: Biomphalaria amazonica - Biomphalaria occidentalis - susceptibility - Schistosoma mansoni - Manso Dam - Brazil

Water resources projects including man-made lakes resulting from damming of rivers cause ecological disturbances which vary in magnitude according to the size of the artificial lakes, their geographic location and the preexisting ecological situation. Such disturbances affect the ecological balance existing between the biological system, including man, and the physical environment, and consequently may introduce certain health hazards that could affect his well-being (Farid 1975). It is impossible to predict accurately the changes that might occur and whether an environment suitable for a snail intermediate host of schistosomiasis will develop, however in countries where the infection is endemic it is prudent that investigations be realized, including studies involving parasite-mollusc compatibility. Although in Brazil such studies are still scarce, Fernandez and Thiengo (2002) demonstrated the possibility of Biomphalaria straminea (Dunker, 1848), found in the lake of Serra da Mesa hydroelectric power station, state of Goiás, to act as a vector of schistosomiasis in that area.

The Manso hydroelectric power station (APM Manso), located in the state of Mato Grosso (S 14 $53^{\prime} \mathrm{W} 55^{\circ} 48^{\prime}$ ), is supplied by two large rivers, Manso and Casca, covering an area of $427 \mathrm{~km}^{2}$ with maximal depth of about $80 \mathrm{~m}$. Among the 21 environmental programs performed in the

\footnotetext{
Financial support: Furnas Centrais Elétricas SA ${ }^{+}$Corresponding author: ammon@ioc.fiocruz.br Received 25 May 2006

Accepted 26 June 2006
}

area that suffered impact from that dam, a survey of freshwater snails was realized for two years (2002-2003), aiming to investigate the occurrence and distribution of those species of medical and veterinary importance. Considering the presence of populations of Biomphalaria in the reservoir of APM Manso and in the surrounding municipalities (Chapada dos Guimarães and Nova Brasilândia) as well as the touristic importance of two of the most famous Brazilian environmental preservation areas in the vicinity, the Parque Nacional da Chapada dos Guimarães and the Pantanal Matogrossense, studies on parasitemollusc compatibility were performed including five colonies of Biomphalaria amazonica Paraense, 1966 and four of Biomphalaria occidentalis Paraense, 1981.

The susceptibility experiments with a sample of $B$. amazonica from Careiro island, exposed to miracidia of two strains of Schistosoma mansoni Sambon, 1907 revealed a potential vector of that trematode (Corrêa \& Paraense 1971). Further experiments with specimens from Porto Velho (Paraense \& Corrêa 1985), showed a lower degree of compatibility between the studied population and the SJ strain, as compared with the control snails. However, these results pointed to the possibility of introduction of schistosomiasis mansoni into the Amazonian region, where this species is widespread. As for $B$. occidentalis, the results of experiments realized (Paraense \& Corrêa 1982, Coimbra Jr \& Engel 1982) revealed unsusceptibility of this species to strains of $S$. mansoni from the states of São Paulo and Pernambuco. These authors however pointed out the need of additional studies with other strains of the parasite.

A total of 257 specimens of B. amazonica were exposed to $S$. mansoni miracidia of the BH strain (158 snails), 
of the SJ strain (44 snails), and of the EC strain (55 snails). Of 222 B. occidentalis snails, 79 were exposed to the SJ strain and 143 to the BH strain. The snails, descendants of specimens obtained in the area of influence of the APM Manso, were individually exposed to five miracidia and three other populations were used as control: 240 specimens of Biomphalaria glabrata (Say, 1818) from Belo Horizonte, state of Minas Gerais, 265 specimens of Biomphalaria tenagophila (Orbigny, 1835) from São José dos Campos, state of São Paulo, and 234 especimens of $B$. straminea from Picos, state of Piauí. The strains were isolated as described by Fernandez (1997) and have been kept in sympatric snails and female Swiss albino mice.

The procedures for collecting feces of infected mice and for late exposure of snails to miracidia were those described by Paraense and Corrêa (1989), and the aquaria were kept at a room temperature of $24-26^{\circ} \mathrm{C}$ throughout the experiment. Snails were observed daily and, if any specimen happened to die, it was dissected and examined for development stages of the schistosome. To characterize the duration of precercarial period and the infection index, the screening techniques used to detect the positive snails were those described by Paraense and Corrêa (1989). The specimens that survived for 60 days after exposure without shedding cercariae were fixed in RaillietHenry's fluid, dissected and examined.

The infection index for B. amazonica varied widely according to the snail populations and the strains used, while all specimens of $B$. occidentalis proved unsusceptible to infection (Table). Of the 17 B. amazonica snails infected (infection index of $6.61 \%$ ), only specimens of the
Barão de Melgaço colony shedded cercariae and the duration of the precercarial period was $38 \pm 0$ days and 27.8 \pm 6.26 days (mean and standard deviation) in the snails exposed BH and SJ strains, respectively. Developing sporocysts were present in one or more external organs (tentacles, mantle collar, head, and foot) in 10 specimens which died between 21 and 48 days post-exposure, and in one which was fixed and examined after the 60th day.

According to the strains used, the results were as follows: of the 158 B. amazonica exposed to BH miracidia, 6 became infected (3.79\%); of the 44 snails exposed to SJ miracidia, 6 became infected (13.63\%); and of the 55 snails exposed to EC miracidia, 5 became infected (9.09\%). As to the controls, $85.41 \%$ of $240 \mathrm{~B}$. glabrata snails $(6-8 \mathrm{~mm}$ in shell diameter) from Belo Horizonte, $40 \%$ of $265 \mathrm{~B}$. tenagophila snails (5-7 mm) from São José dos Campos, and $3.84 \%$ of 234 B. straminea snails $(2.5-7 \mathrm{~mm})$ from Picos, exposed to the BH, SJ, and EC S. mansoni strains, respectively, became infected. As the mortality in the precercarial period: for BH S. mansoni strain, the index was $4.58 \%$ and all showed no infection at dissection; for SJ S. mansoni strain, the mortality index was $7.16 \%$ and of these two showed sporocysts; and for EC S. mansoni strain, this index was $12.39 \%$ and only one of these showed sporocysts in the tissue.

Due to the difficulty to establish B. amazonica under laboratory conditions, few specimens from some colonies were exposed to $S$. mansoni in this study, similarly to Corrêa and Paraense (1971) who used born and reared in laboratory specimens for experimental infection. As for larger samples, the snails used for infection were cap-

TABLE

Infection index in five colonies of Biomphalaria amazonica and four colonies of B. occidentalis to three strains of Schistosoma mansoni

\begin{tabular}{|c|c|c|c|c|c|c|}
\hline & $\begin{array}{l}\text { Colonies of } \\
\text { molluses }\end{array}$ & $\begin{array}{l}\text { Geographical } \\
\text { coordinates }\end{array}$ & $\begin{array}{c}\text { Number of } \\
\text { snails exposed }\end{array}$ & $\begin{array}{l}\text { Shell diameter } \\
\qquad(\mathrm{mm})\end{array}$ & $\begin{array}{l}\text { Strains of } \\
\text { S. mansoni }\end{array}$ & $\begin{array}{c}\text { Index } \\
\text { infection }(\%)\end{array}$ \\
\hline \multirow{5}{*}{ 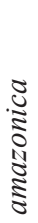 } & Chapada dos Guimarães & $14^{\circ} 52^{\prime} \mathrm{S}$ & 99 & $2.5-4.0$ & $\mathrm{BH}$ & 2.02 \\
\hline & (Manso river) & $55^{\circ} 31^{\prime} \mathrm{W}$ & 7 & $2.0-4.0$ & $\mathrm{SJ}$ & 0 \\
\hline & & & 55 & $2.5-4.5$ & $\mathrm{EC}$ & 9.09 \\
\hline & Chapada dos Guimarães & $15^{\circ} 05^{\prime} \mathrm{S}$ & 16 & $2.0-4.0$ & $\mathrm{BH}$ & 0 \\
\hline & (Casca river) & $55^{\circ} 37^{\prime} \mathrm{W}$ & 10 & $2.5-4.0$ & SJ & 0 \\
\hline \multirow[t]{6}{*}{$\infty$} & Barão de Melgaço & $16^{\circ} 09^{\prime} \mathrm{S}$ & 26 & $2.5-4.0$ & $\mathrm{BH}$ & 11.53 \\
\hline & & $55^{\circ} 53^{\prime} \mathrm{W}$ & 15 & $3.0-5.5$ & $\mathrm{SJ}$ & 33.33 \\
\hline & Poconé & $16^{\circ} 18^{\prime} \mathrm{S}$ & 17 & $2.5-4.0$ & $\mathrm{BH}$ & 5.88 \\
\hline & & $56^{\circ} 32^{\prime} \mathrm{W}$ & 2 & 3.0 & SJ & 0 \\
\hline & Santo Antônio do Leverger & $16^{\circ} 07^{\prime} \mathrm{S}$ & 10 & $2.0-5.0$ & SJ & 10 \\
\hline & & $55^{\circ} 51^{\prime} \mathrm{W}$ & & & & \\
\hline \multirow{8}{*}{ 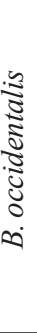 } & Chapada dos Guimarães & $15^{\circ} 08^{\prime} \mathrm{S}$ & 53 & $6.0-6.5$ & SJ & 0 \\
\hline & (Casca river) & $55^{\circ} 40^{\prime} \mathrm{W}$ & & & & \\
\hline & Chapada dos Guimarães & $15^{\circ} 06^{\prime} \mathrm{S}$ & 49 & $3.0-7.0$ & $\mathrm{BH}$ & 0 \\
\hline & (Agua Fria district) & $55^{\circ} 40^{\prime} \mathrm{W}$ & & & & \\
\hline & Santo Antônio do Leverger & $15^{\circ} 55^{\prime} \mathrm{S}$ & 26 & $3.0-8.0$ & SJ & 0 \\
\hline & & $55^{\circ} 30^{\prime} \mathrm{W}$ & & & & \\
\hline & Cuiabá & $15^{\circ} 35^{\prime} \mathrm{S}$ & 94 & $3.0-5.5$ & $\mathrm{BH}$ & 0 \\
\hline & & $56^{\circ} 03^{\prime} \mathrm{W}$ & & & & \\
\hline
\end{tabular}


tured in the field (Paraense \& Corrêa 1985). The present data confirm and enlarge the observations of the abovementioned authors, concerning the susceptibility of B. amazonica to the $\mathrm{BH}, \mathrm{SJ}$, and $\mathrm{EC}$ schistosome strains.

These results also corroborate Corrêa and Paraense (1971), who demonstrated that B. amazonica specimens died before beginning to release cercariae, showing developing sporocysts of the schistosome in the organs. These authors obtained six specimens releasing cercariae (26.08\%) of the 23 infected, after experimental exposition of the 40 snails collected in the Negro river. In this paper, only Barão de Melgaço snails released cercariae (1 specimen exposed to the BH strain and 5 exposed to SJ strain), indicating that few snails survived the incubation period.

Concerning B. occidentalis the present data reinforced this species as refractory to the $S$. mansoni strains used. Paraense and Corrêa (1982) demonstrated unsusceptibility of $B$. occidentalis to infection with SJ S. mansoni strain, using 1582 specimens from ten localities of the states of Mato Grosso, Mato Grosso do Sul, Paraná, and São Paulo. Similarly, Coimbra Jr. and Engel (1982) did not get infection in the two samples analyzed (Acre and Mato Grosso) after experimental exposition to the PE and SP S. mansoni strains; both strains were established in the Centro de Pesquisas René-Rachou, Minas Gerais: the first was isolated from Pernambuco and the second, similarly to SJ strain used in the present study, from the municipality of São José dos Campos.

The apparently low index of the compatibility $B$. amazonica and S. mansoni, as documented by high mortality index, may be due an adjustment between strains of the parasite and snails colonies. Considering all those aspects, we believe that although low, the possibility of introduction of schistosomiasis in the lake as well as in the surrounding municipalities of the APM Manso can not be discarded.

\section{ACKNOWLEDGEMENTS}

To Furnas Centrais Elétricas SA for the facilities provided during the field work, and Dr Lygia dos Reis Corrêa for supplying S. mansoni strains.

\section{REFERENCES}

Coimbra Jr CEA, Engel LA 1982. Suscetibilidade de Biomphalaria occidentalis do Acre e Mato Grosso à infecção pelo Schistosoma mansoni e sua implicação na epidemiologia da esquistossomose na Amazônia Ocidental, Brasil. Acta Amazônica 12: 795-799.

Corrêa LR, Paraense WL 1971. Susceptibility of Biomphalaria amazonica to infection with two strains of Schistosoma mansoni. Rev Inst Med Trop São Paulo 13: 387-390.

Farid MA 1975. The Aswan High Dam development project. In NF Stanley, MP Alpers (eds), Man-made Lakes and Human Health, Academic Press, London, p. 89-102.

Fernandez MA 1997. Schistosoma mansoni infections in the first three months of life of sympatric intermediate hosts from Brazil. Mem Inst Oswaldo Cruz 92: 27-29.

Fernandez MA, Thiengo SC 2002. Susceptibility of Biomphalaria straminea (Dunker, 1848) from Serra da Mesa dam, Goiás, Brazil to infection with three strains of Schistosoma mansoni Sambon, 1907. Mem Inst Oswaldo Cruz 97 (Suppl. I): 59-60.

Paraense WL, Corrêa LR 1982. Unsusceptibility of Biomphalaria occidentalis to infection with a strain of Schistosoma mansoni. Mem Inst Oswaldo Cruz 77: 565-567.

Paraense WL, Corrêa LR 1985. Further experiments on susceptibility of Biomphalaria amazonica to Schistosoma mansoni. Mem Inst Oswaldo Cruz 80: 259-262.

Paraense WL, Corrêa LR 1989. A potential vector of Schistosoma mansoni in Uruguai. Mem Inst Oswaldo Cruz 84: 281-288. 
